Acta regionalia et environmentalica 2

Nitra, Slovaca Universitas Agriculturae Nitriae, 2013, p. 51-54

\title{
ENERGY POTENTIAL IN PRODUCTION OF FAST-GROWING POPLAR CLONES IN SLOVAK REGIONS
}

\author{
Rudolf PETRÁŠ, ${ }^{1}$ Julian MECKO, ' Viera PETRÁŠOVÁ \\ ${ }^{1}$ National Forest Centre - Forest Research Institute, Zvolen, Slovakia \\ ${ }^{2}$ Slovak University of Agriculture in Nitra, Slovakia
}

\begin{abstract}
Calorific value production from the above-ground biomass of stands was derived from its volume production. The mathematical models of growth tables of I-214 and Robusta poplar clones, biomass density values and calorific values of biomass dry matter were used for its calculation. At the stands aged 35 years and site indices of 20,30 and 40, the calorific value has approximately $2.700,6.000$ and $9.300 \mathrm{GJ}$ ha $^{-1}$ respectively. The $\mathrm{I}-214$ clone has higher production than Robusta in the first half of its growth, albeit with minimum differences. The annual increments of calorific value culminate about the age of 9-13 years with values of 450-115

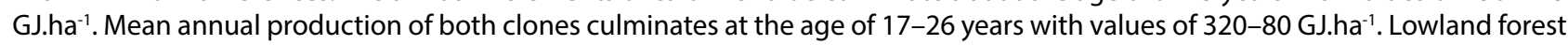
locations with high level of ground water in Slovakia with the total area of 25.600 ha are most suitable for poplars production. On this area, we can assume the mean annual production of $3.566 \mathrm{TJ}$ of gross calorific value obtained from above-ground biomass in the future. From that, about $64 \%$ is in wood, $14 \%$ in bark and $22 \%$ in small-wood. Up to $85 \%$ of this production potential is situated in the area of The Danube Lowland and the rest is mainly in southern areas of the Central and Eastern Slovakia.
\end{abstract}

Keywords: biomass production, poplar clones, calorific value, Slovak regions

Soft wood tree species such as poplars and willows belong to the fast growing tree species in our climate conditions. Regarding the poplars, primarily bred clones reach not only several fold higher production, but also faster wood production than other naturally spread tree species in Slovakia. A stand of poplar clones $1-214$ can reach mean height of $46 \mathrm{~m}$ at the age of 30 years already, and rotation maturity at the age of 20 years with the total mean increment up to $42.5 \mathrm{~m}^{3}$ of diameter inside bark (Petráš a Mecko, 2001) on the best site indices while spruce stands can reach mean height of $42 \mathrm{~m}$ at the age of 100 years and rotation maturity about the age of 80 years with the total mean increment of $17.6 \mathrm{~m}^{3}$ of diameter inside bark on the best site indices. Relatively speaking, mean volume production of the poplar clone is 2.4-times higher and 4-times faster than of spruce which is the most productive tree species in Slovakia. Similar comparison with the most productive beech stands shows that the volume production of poplar clones is 3.5-times higher. So the production potential of poplar clones is extra high and attractive. Even though the stands of poplar clones represent only $0.6 \%$ in Slovakia, these represent the main tree species having dominant commercial importance in lowlands and floodplain forests of Slovakia.

Research of poplar clones in Slovakia is dates back to 1960 s and 1970s of the last century, when their progressive silviculture was introduced into the forest practice. It was focused on individual verifying of the growth and health conditions (Cifra, 1971). Systematic research of bred poplar clones has just started in 1991. It has resulted in creating of models of tree volumes (Mecko et al., 1994), bark diameter (Petráš et al., 1998), height curves (Petráš and Mecko, 2001, 2005), growth and whole stands production (Petráš and Mecko, 2001, 2005), assortments production models (Petráš et al., 2007, 2008), value production (Petráš et al., 2002, 2008) and finally of maturity rotation age and production of calorific value (Petráš et al., 2010, 2012, 2013). Not only the production of wood for wood processing industry should be included here, but also the production of small-wood and bark for energy use.

The aim of this work is to evaluate the possibility of potential production of poplar clones in Slovakia for wider economic and energy use.

\section{Material and methods}

Production of calorific value from above-ground biomass of trees was derived from the calculation of its volume production. In order to calculate it:

- models of growth tables of poplar clones Robusta and I-214 (Petráš and Mecko, 2001, 2005),

- biomass density values (Petráš et al., 2010),

- calorific values of dry matter (Petráš et al., 2013) were used.

Growth table models simulate the volume of trees biomass $V B$ in $\mathrm{m}^{3} \cdot \mathrm{ha}^{-1}$ in relation to their age $t$ and site index of the stand $q$ :

$$
V B=f(t, q)
$$

Site index of the stand is defined by its mean height in the age of 30 years. Biomass is made of wood and non-wood components of whole trees (wood, bark, thinner branches small-wood). Volumes are derived not only for the unevenaged stand, dominant stand, secondary stand, the overall production, but also for the total current increment and the total mean increment. The capacity of calorific values per volume unit $C V\left(G J . \mathrm{m}^{3}\right)$ was calculated from the mean values of density of individual biomass components (fractions) $D$ (kg. $\mathrm{m}^{3}$ ) (Petráš et al., 2010) and from the calorific value of their dry matter CVDM (J.g-1) (Petráš et al., 2013):

$$
C V=D \cdot C V D M \cdot 10^{-6}
$$


The highest capacity of calorific value per volume unit has the smallwood from crown tree parts. The I-214 clone reaches the value of 8.4 and Robusta reaches the value of 8.74 GJ.m $\mathrm{m}^{-3}$, then wood follows with 7.3 and $7.8 \mathrm{GJ}^{-3}$ and the lowest values reaches the bark with 6.9 and 7.0 GJ.m ${ }^{-3}$. The Robusta clone has higher values than 1-214 for all fractions. So, regarding the wood it is a difference by $8 \%$, then for small-wood by $4 \%$ and for the bark only by $2 \%$. These differences are connected with the higher density of all biomass fractions of the Robusta clone (Petráš et al., 2010). Higher content of the calorific value in small-wood probably corresponds to a higher representation of chemical substances such as lignin, lipids and terpenes. All biomass fractions have relatively low variability of the calorific value. Variation coefficients mostly range from $6 \%$ to $10 \%$.

Production of the calorific value of whole stands was derived from inserting the mean calorific values according to a formula (2) to the relation (1). Then, a resulting model implies production of calorific value CV (GJ.ha-1) of poplar clones stands in dependence to their age $t$ and site index $q$ according to a formula:

$$
C V=f(t, q)
$$

\section{Results and discussion}

\section{Model production of the calorific value}

Lifelong production of the calorific value in above-ground biomass parts of poplar clones stands (Figure 1) has a shape of growth curves and is distinctively graduated by site indices of stands. Calorific value reaches the figures of approximately 2.700, 6.000 and $9.300 \mathrm{GJ}^{-h^{-1}}$ in the stand age of 35 years and site indices 20, 30, 40 . Then, I-214 clone has higher production than Robusta in the first half of life, but the differences are minimal. Annual increments of calorific value (Figure 2) culminate roughly in the age of 9-13 years with the values of 450-115 $\mathrm{GJ}^{-1} \mathrm{a}^{-1}$. The I-214 clone increments culminate only 1-2 years earlier than those of Robusta. Similar course shows the mean annual production of both

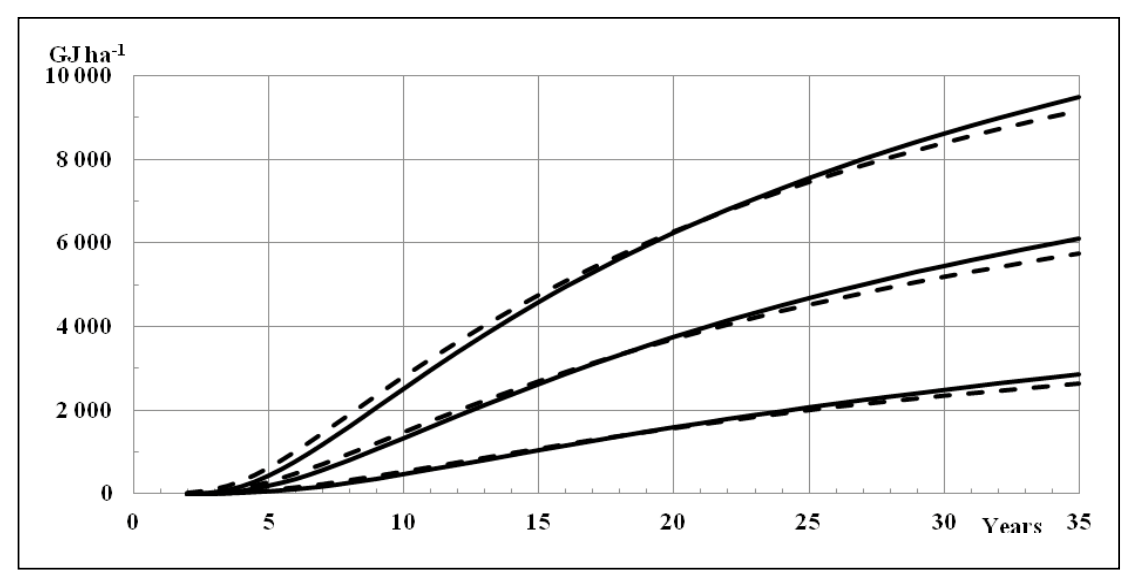

Figure 1 Total production of calorific value of Robusta poplar clones (bold line) and of the $\mathrm{I}-214$ clone (dashed line) in dependence on the age and site index of the stand $(20,30,40$ - lower, middle and upper lines)



Figure 2 Annual increments and mean annual production of calorific value of Robusta poplar clones (bold line) and of the I-214 clone (dashed line) in dependence on the stand age. Lower lines correspond to the site index of 20 and upper to the site index of 40

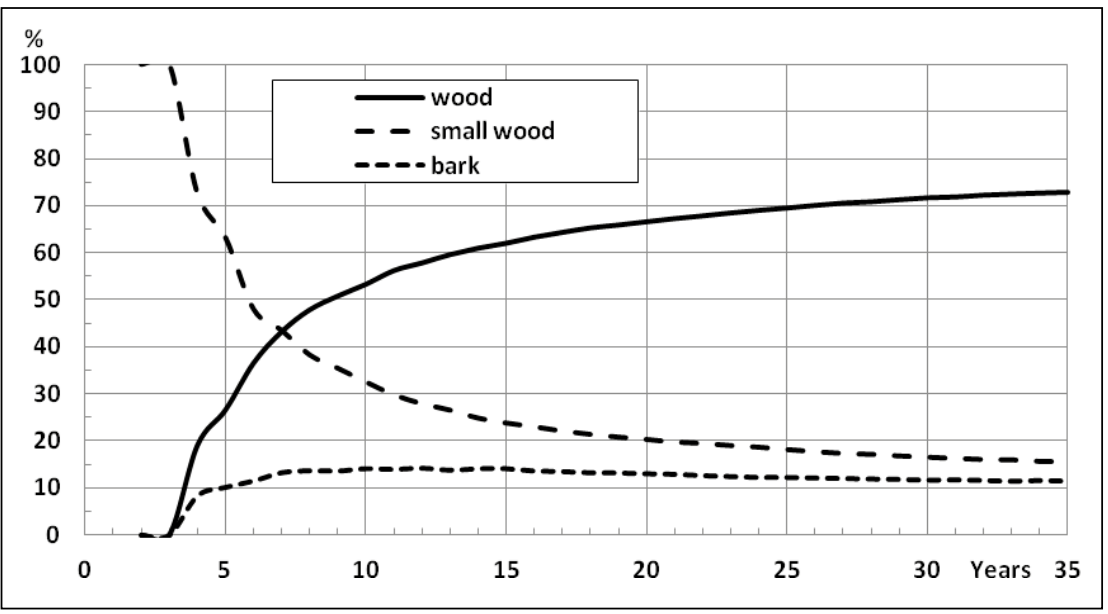

Figure 3 Development of the share of calorific value in wood, bark and small-wood at biomass producing of the Robusta clone, the site index of 30 and in dependence on the stand age

clones. It culminates about the age of $17-26$ years with the values of $320-80$

GJ.ha-1 for both clones. The stand ages in which their annual mean production 
culminates are considered as optimum ages for cutting and processing these stands.

Calorific value accumulates itself differently in individual biomass fractions (Figure 3). Its share in wood increases with the stand age, but decreases in the bark and small-wood in particular; $75 \%$ of the calorific value accumulates in wood, $15 \%$ in the small-wood and $10 \%$ in the bark in the age of 35 years. This knowledge is important for considerations about using this poplar clone biomass for the industry. Wood from the stem base and from the middle of stem has less calorific value per $1 \mathrm{~m}^{3}$ and not only from this reason is it useful to use it typically, so by current mechanical or chemical processing. Bark has lower calorific value per $1 \mathrm{~m}^{3}$ in comparison to wood, but efficiency of its energy use multiplies the fact that costs on its production including transport to a consumption place are accounted for the industry wood which is delivered with the bark to its processors. It is necessary to emphasize that energy potential of small-wood of tree crowns which remains lying in the forest as a waste after the harvest is relatively insufficiently used in practice.

\section{Production potential of calorific value \\ of poplar clones in Slovakia}

The representation of not only poplar stands, but also willow stands decreases in last decades in Slovakia. It is proved by the areas showed in Permanent forest inventories (PFI) carried out in 1980, 2003 and 2011 (Table 1).

It is evident that the area of poplar stands decreased to less than $79 \%$ and of willow stands to $56 \%$ of the area from 1980. Area for both groups of stands decreased to $75 \%$ approximately. In addition to this area, it is also necessary to take into consideration the poplar wood production in riparian stands

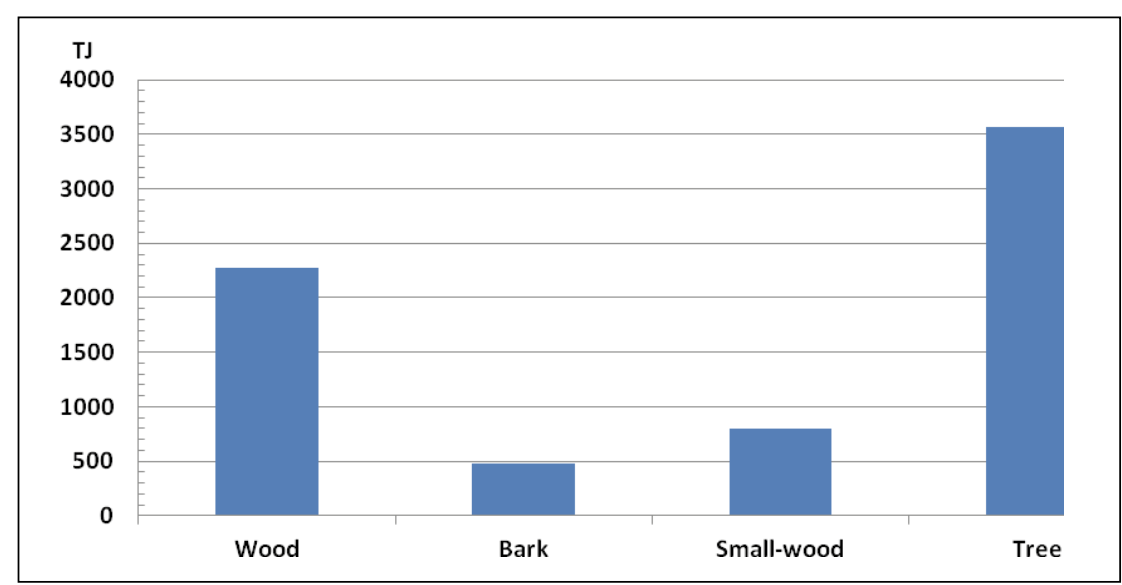

Figure 4 Mean annual production of calorific value from above-ground biomass of poplar clones stands with the average site index of 26 and rotation period of 20 years

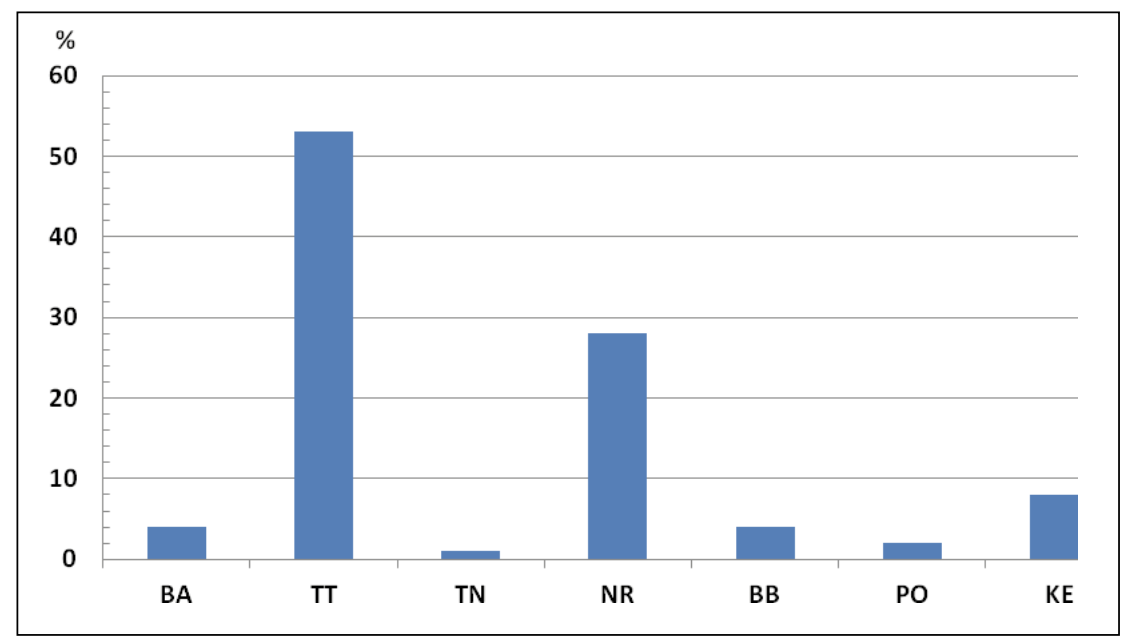

Figure 5 Share on potential production of poplar clones by regions

BA - Bratislava, TT - Trnava, TN - Trenčín, NR - Nitra, BB - Banská Bystrica, PO Prešov, KE - Košice

of water resources and shelterbelts. However, their area has not been inventoried yet. Although the area of poplar stands decreased in last decades, it is necessary to consider its extension in the future, i.e. mainly on agricultural lands. This trend is expected with the SR membership in the EU and its agricultural policy which supports nonagricultural production on lands. It is also established by the last amendment of the Act no. 220/2004 on protection and use of agricultural land.

Table 1 Development of the poplar and willow stands area in Slovakia

\begin{tabular}{|l||c|c|c|c|}
\hline \multirow{2}{*}{ Stands } & $\mathbf{1 9 8 0}$ & $\mathbf{2 0 0 3}$ & \multicolumn{2}{|c|}{$\mathbf{2 0 1 1}$} \\
\cline { 2 - 5 } & ha & ha & ha & $\%$ \\
\hline Poplar & 21,002 & 17,708 & 16,564 & 78.9 \\
\hline Willow & 3,478 & 2,240 & 1,946 & 56.0 \\
\hline In total & 24,480 & 19,948 & 18,510 & 75.6 \\
\hline
\end{tabular}

According to Remiš (1983), lowland forest locations with high ground water level and the forest types $Q F r$ with the area of 4,650 ha and UFrpopuleum with the area of 3,950 ha are the most suitable types for poplar silviculture, but UFr-carpineum with the area of 17,000 ha is also a satisfactory forest type. Thus, it is 25,600 ha in total. Assuming that poplar clones would be cultivated on this area with an average site index 26 and rotation period of 20 years, we can estimate the mean annual production of 3,566 TJ of calorific value from the above-ground tree biomass (Figure 4). Then, it is about 2,278 TJ (64\%) in wood wide $7 \mathrm{~cm}$ and more, 484 TJ (14 \%) in bark from this wood and 804 TJ (22\%) in small-wood which is a wood with a bark thinner than $7 \mathrm{~cm}$. According to the representation of production areas for cultivating the 
poplar clones (Figure 5), we can state that up to $85 \%$ of production potential is in the area of the Danube Lowland regions of Trnava, Nitra and Bratislava - and remaining $15 \%$ is in southern areas of Košice and Banská Bystrica regions.

\section{Conclusions}

The production of above-ground biomass from poplar clones incorporates wood for industrial, chemical and mechanical processing and bark and small-wood from tree crowns for energy use. The highest capacity of calorific value per volume unit has small-wood from crown tree parts. The clone I-214 has the value of 8.4 , and Robusta $8.74 \mathrm{GJ}^{-3} \mathrm{~m}^{-3}$, wood has 7.3 and $7.8 \mathrm{GJ}^{-3} \mathrm{~m}^{-3}$ and bark with 6.9 and $7.0 \mathrm{GJ}^{-3} \mathrm{~m}^{-3}$ has the least value. The clone Robusta marks higher values than the I-214. It is by $8 \%$ at wood comparison, by $4 \%$ for small-wood and by $2 \%$ for the bark comparison. These differences relate primarily to higher density of all biomass fractions of the Robusta clone. The production of calorific value of above-ground poplar stands biomass is distinctively graduated by site indices of these stands. Calorific value reaches the figures of approximately 2,700, 6,000 and 9,300 GJ.ha-1 for the stand age of 35 years and site indices 20,30,40. Mean annual production culminates at the age of 17-26 years with the values of $320-80$ GJ.ha $^{-1}$. Lowland forest locations with the high level of ground water are most suitable for cultivating the poplars. Annual mean production of tree biomass with the values of 3,566 TJ is expected on the area of approximately 25,600 ha. Roughly $64 \%$ of it is in the wood, $14 \%$ in the bark and $22 \%$ in smallwood. Majority of production potential, up to $85 \%$, lies within the area of The Danube Lowland - regions of Trnava, Nitra and Bratislava and remaining 15\% within southern parts of Košice and Banská Bystrica regions.

\section{Acknowledgement}

This paper was supported by the Slovak Research and Development Agency under the contract no. APVV-0131-07.

\section{References}

CIFRA, J. 1971. Doterajší rast topol'ov v pokusných lignikultúrach na Slovensku. In Lesnícky časopis, roč. 17, 1971, č. 2,s. 259-271. MECKO, J. - PETRÁŠ, R. - NOCIAR, V. - GECOVIČ, M. 1994. Konštrukcia objemových tabuliek topolových klonov Robusta a I-214. In Lesnictví, roč. 40, 1994, č. 10, s. 446-454.
PETRÁŠ, R. 1992. Slobodova diferenciálna rovnica v konštrukcii výškových bonitných kriviek topol’ových klonov. In Lesnícky časopis, roč. 38, 1992, č. 2, s. 147-156.

PETRÁŠ, R. - MECKO, J. - NOCIAR, V. 1998. Hrúbka kôry topolovej gulatiny klonov Robusta a I-214. In Lesnícky časopis Forestry Journal, roč. 44, 1998, č. 5, s. 321-328.

PETRÁŠ, R. - MECKO, J. 2001. Erstellung eines mathematischen Modells der Ertragstafeln für Pappelklone in der Slowakei. In Allg. Forst-u. J.-Ztg., vol. 172, 2001, no. 2, pp. 30-34.

PETRÁŠ, R. - MECKO, J. - PETRÁŠOVÁ, V. 2002. Vývoj cien surového dreva hospodársky významných drevín Slovenska. In Lesnícky časopis - Forestry Journal, roč. 48, 2002, č. 2, s. 91-106. PETRÁŠ, R. - MECKO, J. 2005. Rastové tabul'ky topolových klonov. Bratislava : Slovak Academic Press, 2005, s. 135.

PETRÁŠ, R. - MECKO, J. - NOCIAR, V. 2007. Modely kvality surového dreva stromov topol'ových klonov. In Lesnícky časopis - Forestry Journal, roč. 53, 2007, č. 2, s. 83-97.

PETRÁŠ, R. - MECKO, J. - NOCIAR, V. 2008. Quality of wood in the stands of poplar clones. In Journal of Forest Science, vol. 54, 2008, no. 1, pp. 9-16.

PETRÁŠ, R. - MECKO, J. - NOCIAR, V. 2008. Value production of poplar clones. In Journal of Forest Science, vol. 54, 2008, no. 6, pp. 237-244.

PETRÁŠ, R. - MECKO, J. - NEUSCHLOVÁ, E. 2010. Density of basic components of above-ground biomass of poplar clones. In Wood Research, vol. 55, 2010, no. 4, pp. 113-122.

PETRÁŠ, R. - JAMNICKÁ, G. - MECKO, J. - NEUSCHLOVÁ, E. 2012. State of Mineral Nutrition and Heavy Metals Distribution in Aboveground Biomass of Poplar Clones. In Polish Journal of Environmental Studies, vol. 21, 2012, no. 2, pp. 447-453.

PETRÁŠ, R. - MECKO, J. - OSZLÁNYI, J. - PETRÁŠOVÁ, V. JAMNICKÁ, G. 2013. Landscape of Danube inland-delta and its potential of poplar bioenergy production. In Biomass and Bioenergy, vol. 30, 2013, p. 68-72.

REMIŠ, J. 1983. Zvyšovanie objemovej a hodnotovej produkcie zakladaním intenzívnych porastov. In Záverečná správa, Zvolen :VúLH, 1983, s. 65.

\section{Contact address:}

doc. Ing. Rudolf Petráš, CSc., National Forest Centre - Forest Research Institute in Zvolen, T. G. Masaryka 22, 96092 Zvolen, Slovakia, e-mail: petras@nlcsk.org 